Potravinarstvo Slovak Journal of Food Sciences vol. 15, 2021, p. 891-900

https://doi.org/10.5219/1597

Received: 22 March 2021. Accepted: 26 September 2021. Available online: 28 October 2021 at www.potravinarstvo.com (C) 2021 Potravinarstvo Slovak Journal of Food Sciences, License: CC BY 4.0

ISSN 1337-0960 (online)

\title{
THE INFLUENCE OF VARIETAL CHARACTERISTICS ON THE QUALITY INDICATORS OF CANDIED FRUITS FROM PLUM FRUITS
}

\author{
Tatiana Prichko, Natalia Droficheva
}

\begin{abstract}
The influence of varietal characteristics of plum fruits on the physicochemical parameters of the drying process has been investigated. Revealed significant differences in the content of biologically active compounds on the example of varieties: Stanley, Big Stanley, Grossa di Felisio, President, Blue moon, August Delish, Kabardinskaya early. The consumption rates of raw materials for the production of candied fruits have been determined. The results of laboratory studies on the variation of the content of vitamins $(C, P)$, anthocyanins in plum fruits, taking into account varietal characteristics, are presented. The drying process on a dryer with infrared rays led to a slight decrease in polyphenolic and mineral substances, and higher losses of vitamins in the finished candied fruit. The mathematical processing of the experimental data was carried out by the method of analysis of variance and descriptive statistics using the Microsoft Excel software package. In the production of candied plum fruits, optimal technological modes have been selected that contribute to a high yield of high-quality finished products, taking into account the varietal characteristics of the feedstock. According to biochemical and organoleptic indicators of the quality of candied fruits, Stanley and President varieties were distinguished, the energy value of which is $147.0 \mathrm{kcal}$ with an organoleptic assessment of 4.9 points. The results of experimental biochemical and technological analyzes of fruits at individual technological stages of production made it possible to assess the intensity of complex processes that cause a qualitative transformation of raw materials.
\end{abstract}

Keywords: plum; technological process; candied fruits; physical methods; organoleptic indicators

\section{INTRODUCTION}

Plum is a high-yielding stone fruit plant, the origin of which is the result of a natural hybridization of cherry plum and blackthorn, which historically occurred in the Caucasian and Asia Minor regions. Plum cultivation continued in the Mediterranean and Central Asia. From Mediterranean Italy, plum has penetrated European countries and has firmly taken the position of one of the most popular fruit trees in the world of fruit growing (Doroshenko, Ryazanova and Maksimtsov, 2015; Eremin et al., 2000; Popova et al., 2020). The scientific interest in studying the medicinal properties of plums is explained by the high content of phenols in its fruits, mainly anthocyanins, which are natural antioxidants (Prichko, 2009; Kim, Jeong and Lee, 2003; Gościnna et al., 2021). Many world scientists have substantiated the connection between the use of plums and the improvement of cognitive function (in particular, a positive effect on memory and related processes) (Igwe and Charlton, 2016; Turaeva, 2017). In addition to the aforementioned and antioxidant properties, the interrelation of the inclusion of plum fruits in the diet and the reduction of risk factors for cardiovascular diseases is emphasized.The antiinflammatory, analgesic, antibacterial and anti-cancer properties of home plum gum have been analyzed in dozens of studies (Islam et al., 2017; Milskaya, 1998). Several scientific works emphasize the following: the chemical composition of plum fruits allows the use of this fruit as a source of raw materials for the production of candied fruits and dried fruits. As a rule, fresh fruits and vegetables have a short shelf life, since various microbes and enzymes affect them and quickly spoil. Therefore, fresh fruits and vegetables must be eaten immediately, and the surplus must be skillfully preserved for the autumn-winter and spring periods. In this regard, the development and implementation of modern processing technologies for perishable raw materials in the form of fruits, fruits, and vegetables with full preservation of the nutritional and taste qualities of the final product is relevant in the modern world (Prichko, Machneva and Droficheva, 2020; Amin et al., 2019, Svanes and Johnsen, 2019). Candied fruit - fruit processing products made by single or multiple cooking in sugar syrup, dried to a mass fraction of dry matter of at least $80 \%$, sprinkled with sugar, powdered sugar, or glazed (GOST 28322, 2014). American scientists in the course of a retrospective study found that dried fruits are no less beneficial for health than fresh ones, and in winter they can be successfully replaced (Sullivan et al., 2020). The analysis made it possible to conclude the relevance of research in the field of processing plum fruits 
into dried fruits and candied fruits. In this regard, it is of interest to study the influence of varietal characteristics on the quality indicators of candied fruits.

\section{Scientific hypothesis}

As a result of the analysis of the dynamics of changes in the biochemical indicators of the quality of plum fruits, a working hypothesis was put forward about the influence of varietal characteristics of fruits on the quality indicators of processed products, in particular candied fruits. This served as the basis for experimental studies of the systemic influence of the varietal characteristics of plum fruits on the physicochemical parameters of the technological process of drying and finished products.

\section{MATERIAL AND METHODOLOGY \\ Samples}

Fresh fruits of domestic plum (Prunus domestica) varieties: Stanley, Big Stanley, Grossa di Felisio, President, Blue moon, August Delish, Kabardinskaya early. The material for the research was obtained in the industrial plantings of domestic plum, JSC "Plodovod" (Krasnodar), planted in 2006;

Candied plum fruit varieties: Stanley, Big Stanley, Grossa di Felisio, President, Blue moon, August Delish, Kabardin early. Candied fruits were obtained in the laboratory for storage and processing of fruits and berries in 2020.

\section{Chemicals}

To assess the chemical composition and quality indicators of fresh plum and candied fruits in a varietal section, reagents of the following qualifications were used:

- 2,6-dichlorophenolindophenolate sodium, mass concentration 0.250 g. ${ }^{\text {dm-3 }}$; JSC "Vekton", chemically pure;

- $\quad$ ascorbic acid - 1.0 and 0.1 g. ${ }^{\mathrm{dm}-3}$; JSC "Vekton", chemically pure;

- nitric acid according to GOST 4461 with a density of $1.41 \mathrm{~g} .{ }^{\mathrm{cm}-3}$; JSC "Vekton", chemically pure;

- metaphosphoric acid according to GOST 841, solutions with a mass fraction of 3 and $6 \%$; JSC "LenReaktiv", reagent grade hydrochloric acid according to GOST 3118 with a density of 1.19 g. ${ }^{\mathrm{cm}-3}$; JSC "Vekton", chemically pure;

- glacial acetic acid according to GOST 61 and a solution with a mass fraction of 3\%; JSC "Vekton", chemically pure;

- $\quad$ sulfuric acid according to GOST 4204, chemically pure grade, with a density of $1836 \mathrm{~kg} . \mathrm{m}^{-3}$; JSC "Vekton", chemically pure;

- $\quad$ oxalic acid according to GOST 22180, chemically pure grade; JSC "Uralkhiminvest", chemically pure;

- perchloric acid, solution of molar concentration 0.1 mol.dm ${ }^{-3}$; JSC "Vekton", chemically pure; ethylenediaminetetraacetic acid with a mass fraction of 5\%; JSC "Vekton", chemically pure; orthophosphoric acid according to GOST 6552-80; JSC "Vekton", chemically pure;

- potassium iodide according to GOST 4232, a solution with a mass fraction of $1 \%$ in a solution of acetic acid with a mass fraction of $3 \%$; JSC "LenReaktiv", reagent grade;
- $\quad$ formaldehyde with a mass fraction of $36-40 \%$; JSC "Vekton", chemically pure;

- buffer solutions with pH 4.01 and 9.18; JSC "Uralkhiminvest", chemically pure;

- $\quad$ sodium hydroxide in accordance with GOST 4328, phenolphthalein with a mass concentration of 10 g.dm ${ }^{-3}$; JSC "Uralkhiminvest", chemically pure;

- acetone in accordance with GOST 2603; JSC "Vekton", chemically pure;

- sodium phosphate disubstituted according to GOST 4172 with a mass concentration of 200 g.dm ${ }^{-3}$; JSC "Vekton", chemically pure;

- $\quad$ sodium sulfate 10-water in accordance with GOST 4171; JSC "Vekton", chemically pure;

- potassium ferrous-cyanide 3-water in accordance with GOST 4207; JSC "Vekton", chemically pur;

- zinc acetate 2-water in accordance with GOST 5823 with a mass concentration of 230 g. $\mathrm{dm}^{-3}$; JSC "LenReaktiv", reagent grade;

- $\quad$ zinc sulfate 7-water in accordance with GOST 4174; JSC "LenReaktiv", reagent grade;

- acetic acid lead according to GOST 1027; JSC "LenReaktiv", reagent grade;

- copper (II) sulfate pentahydrate according to GOST 4165; JSC "Vekton", chemically pure;

- $\quad$ sodium hydroxide following GOST 4328, with a mass concentration of $10 \mathrm{~g} . \mathrm{dm}^{-3}$; JSC "Vekton", chemically pure;

- $\quad$ iron ammonium alum according to NTD; JSC "Vekton", chemically pure;

- potassium permanganate according to GOST 20490; JSC "Uralkhiminvest", chemically pure;

- methyl orange with a mass concentration of 1 g.dm- ${ }^{3}$; JSC "Vekton", chemically pure;

- distilled water according to GOST 6709 or water of equivalent purity, etc.

Tools

- $\quad$ Refractometer - PAL-H Digital refractometer for sauces and purees $0.093 .0 \%$ for high-temperature samples; "ATAGO"; Japan;

- $\mathrm{pH}$ Meter - ST2100-E Laboratory $\mathrm{pH} /$ ORP; "Ohaus";

- Electronic laboratory scales AF-R220CE, "VIBRA", LLC "Eykom Msk";

- Water jet pump in accordance with GOST 25336, JSC "LenReaktiv";

- Hourglass clock for 2, 3, 5 minutes or stopwatch; LLC "First Thermometer Plant";

- Homogenizer - rotary, up to $10,000 \mathrm{rpm}$, UltraTurrax T 50 digital; manufacturer "IKA";

- Gas chromatograph "Crystal - 2000M" - reg. No. 14516-12; manufacturer "GRANATE";

- DROP-103RT; manufacturer - Tech Equipment LLC, St. Petersburg;

- $\quad$ "KAPEL $®-105 \mathrm{M}$ ", data collection and processing using specialized software "Elforan"; manufacturer - LLC "Lumex-marketing";

- Water bath - six-seater UT-4300E ULAB, manufacturer - ULAB;

- Laboratory centrifuge Armed LC-04B; manufacturer - NV-LAB; 
- Liquid chromatograph (operating range of absorption wavelengths from 200 to $600 \mathrm{~nm}$ ); "LYUMAKHROM";

HPLC column; brand - Phenomenex Luna; "LYUMAKHROM;

water bath - six-seater UT-4300E; ULAB; laboratory centrifuge Armed LC-04B; NV-LAB; utensils (ISO 835-1-81, ISO 1042-83, ISO 4788$80)$;

flasks in accordance with GOST 1770, 1-250-2 or 2-250-2; LLC "MiniMedProm";

pipettes according to NTD, 2-2-25 or 2-1-25, 2-250 or $2-1-50,2-2-100$ or 2-1-100; LLC "MiniMedProm";

burettes according to NTD, 1-2-25-0.1 or 2-2-250.1 or 3-2-25-0.1; LLC "MiniMedProm";

conical flasks in accordance with GOST 25336, Kn-2-250-34 THS; LLC "MiniMedProm";

glasses following GOST 25336, V-1-50 TS, N-1100 TS, V-1-250 TS; LLC "MiniMedProm";

laboratory funnels following GOST 25336, B-56$80 \mathrm{XC}$ or B-75-140 XC or B-100-150 XC; LLC "MiniMedProm";

a stick made of chemical laboratory glass following GOST 21400; LLC "MiniMedProm";

laboratory porcelain mortar and pestle following GOST 9147, respectively, with an outer diameter of 70 or $90 \mathrm{~mm}$ and a height of $90 \mathrm{~mm}$;

laboratory glass measuring cylinders following GOST 1770 with a capacity of $100,250 \mathrm{~cm}^{3}$; LLC "MiniMedProm";

laboratory thermometer with a measurement range of $0{ }^{\circ} \mathrm{C}-100{ }^{\circ} \mathrm{C}$, with a graduation value of not more than $0.5^{\circ} \mathrm{C}$ following GOST 28498; LLC "First Thermometer Plant";

laboratory glass dropper following GOST 25336; LLC "MiniMedProm";

chromatographic micro tweezers with a capacity of $10 \mathrm{~mm}^{3}$, a graduation rate of $0.1 \mathrm{~mm}^{3}$ and a capacity of $20 \mathrm{~mm}^{3}$; membrane filters with pore diameters of 0.20 and 0.45 microns for filtering the mobile phase and samples; "LYUMAKHROM".

\section{Laboratory methods}

In the process of studying the influence of varietal characteristics of plum fruits for use in the food processing industry in the laboratory for storage and processing of fruits and berries of FSBSI NCFSCHVW, technical and biochemical quality indicators were determined using modern methods and GOSTs (GOST 26313; GOST 26671, 2014; GOST 25555.0, 1982; GOST ISO 2173, 2014; GOST 24556, 2014; GOST 32709, 2014; Yakuba, Kuznetsova and Lozhnikova, 2011; Methods of analysis, 2002; Vigorov, 1972; GOST 31745, 2012; GOST 8756.1, 1987). Sampling - following GOST 26313 (2013), sample preparation - following GOST 26671 (2014); determination of soluble dry substances (RSV) in fruits and candied fruits was carried out by refractometric method according to GOST ISO 2173 (2014); the content of titratable acids by the potentiometric method following GOST 25555.0-82 (1982); the content of vitamin C by a titrometric method according to GOST 24556 (2014); common sugars by photocolorimetric method on a photoelectric colorimeter; the content of total polyphenols and P-active substances was determined by the method of L. I. Vigorov on a KFK-2 photoelectric colorimeter; the content of water-soluble plant pigments (anthocyanins), by the method of $\mathrm{pH}$ differential spectrophotometry following GOST 32709 (2014). Flesh hardness using FT - 372 penetrometer with $8 \mathrm{~mm}$ plunger after skin removal. The amino acid composition in plums and candied fruits was determined by the method of highly efficient capillary electrophoresis on a KAPEL-103RT device. Determination of the content of polycyclic aromatic hydrocarbons (aromatic substances) in the test samples was determined by the method of highperformance liquid chromatography on a gas chromatograph "Crystal - 2000M" following GOST 31745 (2012). The organoleptic indices of the tasting evaluation of candied fruits from plum fruits in the varietal section were determined following GOST 8756.13-79 (1987).Experiment Description

Sample preparation following GOST 26313 (2014), GOST 26671 (2014).

The number of analyzed samples -8 varieties of fresh fruits and candied fruits: Stanley, Big Stanley, Grossa di Felisio, President, Blue moon, August Delish, Kabardinskaya early.

Number of replicates: Assays were performed in duplicate.

Number of repetitions of the experiment: The experiment was carried out in triplicate.

\section{Statistical Analysis}

When processing experimental data for a significance level of $p=0.05$, the following statistical criteria were used: Cochran's criterion - to assess the homogeneity of the variance; Student's test - to assess the significance of the calculated coefficients; Fisher's criterion - to assess the adequacy of the obtained regression equations. Calculations were performed using the Microsoft Excel 2020 software package (Microsoft XLSTAT).

\section{RESULTS AND DISCUSSION}

The taste and technological qualities of plums are largely determined by their chemical composition (Eremin et al., 2009). On the example of 7 plum varieties investigated in the laboratory for storage and processing of fruits and berries of the FSBSI NCFSCHVW, technical indicators of fruits are presented (Table 1).

The studied varieties vary significantly in the content of dry substances, sugars, acids, vitamins, and polyphenolic substances (Table 2).

There is a wide range of variation in the acid content in plum fruits $0.72-1.31 \%$. The varieties such as Blue Moon, Big Stanley, and August Delish stand out for their high acidity. The Blue Moon variety (sugar-acid index 8.4) has the sourest taste.

The plum culture is characterized by a low content of vitamin $C$ (a natural antioxidant), on average $5-6 \mathrm{mg} \cdot 100 \mathrm{~g}^{-1}$. The varieties Blue Moon and Grossa di Felisio with an increased level of vitamin $C$ accumulation $7.0-7.5 \mathrm{mg} .100 \mathrm{~g}^{-1}$ were identified. In terms of the amount of vitamin $P$, plum varieties differ 2 times: Big Stanley fruits accumulate up to $40 \mathrm{mg} \cdot 100 \mathrm{~g}^{-1}$, and Stanley varieties 
more than $70 \mathrm{mg} \cdot 100 \mathrm{~g}^{-1}$. The total content of polyphenolic substances varies slightly, taking into account the variety, from $166.4 \mathrm{mg} .100 \mathrm{~g}^{-1}$ (Big Stanley variety) to 189.0 mg. $100 \mathrm{~g}^{-1}$ (Grossa de Felisio variety), which also form the antioxidant activity of fruits (Sheikh, Saini and Sharma, 2021; Demidov, Popov and Savelyev, 2015; Qin et al., 2020; Li et al., 2021; Makarova and Eremeeva, 2015). Large varietal differences can be traced in the content of anthocyanins: $60.2 \mathrm{mg} .100 \mathrm{~g}^{-1}$ for the Blue Moon variety, $32.9 \mathrm{mg} .100 \mathrm{~g}^{-1}$ for the Big Stanley variety (Figure 1).

The composition of free amino acids is presented in detail in two studied varieties: Stanley and President. In the fruits of the Stanley variety, 12 amino acids were identified, which is $71.3 \mathrm{mg} .100 \mathrm{~g}^{-1}$, including arginine 2.1, phenylalanine 0.1 , histidine 0.37 , leucine 0.18 , methionine 2.6 , valine 0.18 , proline 19.0 , threonine 42.5 , tryptophan 2.8 , serine 0.42 , alanine 0.96 , glycine $0.02 \mathrm{mg} .100 \mathrm{~g}^{-1}$.

It has been established that the amino acid composition of the fruit of the President variety is represented by 13 amino acids, including five essential ones (methionine, phenylalanine, leucine, valine, and threonine). Among the essential amino acids, methionine was found in the maximum amount $\left(3.8 \mathrm{mg} \cdot 100 \mathrm{~g}^{-1}\right)$, the content of phenylalanine is $0.27 \mathrm{mg} .100 \mathrm{~g}^{-1}$, leucine $0.24 \mathrm{mg} .100 \mathrm{~g}^{-1}$, valine $-0.45 \mathrm{mg} .100 \mathrm{~g}^{-1}$. The amount of threonine is less than $0.1 \mathrm{mg} \cdot 100 \mathrm{~g}^{-1}$. Among the nonessential amino acids, the maximum amount contains arginine (0.62 mg.100g $\left.\mathrm{g}^{-1}\right)$, proline $\left(2.4 \mathrm{mg} .100 \mathrm{~g}^{-1}\right)$, and $\alpha$-alanine.

The aroma-forming substances of the fruits of the President variety are represented by 3 aldehydes (acetaldehyde, furfural, 5-methyl furfural), the total amount of which is $2.2 \mathrm{mg} \cdot 100 \mathrm{~g}^{-1}$. In addition to them, 2 saturated aliphatic carboxylic acids were noted - propionic and acetic in the amount of $8.2 \mathrm{mg} .100 \mathrm{~g}^{-1}$, as well as a small amount of aromatic and aliphatic alcohols and esters.

In the new varieties August Delish, Big Stanley, Grossa di Felisio, President in 2020, a complex of macronutrients was investigated, which makes it possible to establish that plum is a valuable raw material for the production of canned food enriched with minerals. The fruits contain a significant amount of potassium, sodium, and, which is very important for the processed raw materials, calcium, which can maintain the structure of the fruit tissue during processing (Table 3).

The data given in the tables allow us to conclude that each variety is characterized by its own set of biologically active substances and is of interest to food processing enterprises. According to the results of evaluating the technical indicators of plum fruits for 2019 - 2020, the most interesting for the production of candied fruits is the variety: President, Grossa de Felisio, August Delish, the fruits of which were processed in comparison with the control, which has wide production plantings in the territory of the Russian Federation (variety Stanley) (Kaufmane et al., 2007; Prichko and Droficheva, 2019).

Candied fruits are complex drying objects, where it is necessary to take into account such indicators as the initial and final moisture content, chemical composition, structural and mechanical changes, and mass transfer characteristics. Candied fruit drying is a process that, in essence, is not only thermophysical but also technological (Meretukova,
2012). As a technological process, drying of fruits and other moist materials is a combination of heat and mass transfer processes, accompanied by biochemical, technological, and structural-mechanical changes. When dried in candied fruits, not only the native properties of the product should be preserved, but also be significantly improved. The main feature of the process of sorption of raw materials is that the mechanical, thermophysical, diffusion properties of the raw materials change significantly upon saturation, which has a significant effect on all subsequent technological operations (Deiana et al., 2019; Gonzalez-Cebrino et al., 2013; Gonzalez et al., 2016).

The fruits, after pitting and blanching, were kept in sugar syrup three times for 4 to 6 hours. For the production of candied fruits from plum fruits, a high initial concentration of syrup is undesirable, because this increases the stickiness of the fruit, which significantly reduces the attractiveness of the appearance of the finished product (Alekseeva et al. 2018; Cerri et al., 2019; Reichel et al., 2017; Richmond, Bowyer and Vuong, 2019; Sommano et al., 2013). The change in the concentration of the syrup in the first period of exposure between the fruit and the syrup is achieved mainly due to their dehydration and due to this dilution of the concentration of the syrup. After 4 hours of exposure, the concentration of the syrup decreases to $45-50 \%$ and insignificant phase changes are already taking place in the system. The third filling is carried out with part of the released syrup, brought to $60 \%$ concentration. During this period, the phenomenon of dehydration of fruits was also noted with a simultaneous, but already less saturation of them with syrup.

At this technological stage of candied fruit production, the following varieties proved to be unsuitable for this type of processing of plum fruits: Blue moon and August Delish. The fruits of the Blue Moon variety did not hold their shape after the first pouring with syrup, and the fruits of the August Delish variety lost a significant amount of coloring pigment and acquired a pale appearance.

Optimization of drying processes in a drying oven with IR rays has been carried out under conditions that prevent sugar caramelization, protein denaturation, which worsen the presentation and quality of candied fruits (Nunes et al., 2009a; Nunes et al., 2009b). Plum fruits were dried in 2 stages: in the first two hours at a temperature of $40-45^{\circ} \mathrm{C}$, then the temperature was increased to $60-65{ }^{\circ} \mathrm{C}$ for $4-5$ hours. If necessary, especially for large fruits, the raw material was dried at $40{ }^{\circ} \mathrm{C}$ to a moisture content of $20-23 \%$. During the drying process, the raw materials were periodically turned over and the temperature in the drying oven was controlled. The drying time is determined by the intensity of the technological process, the type and size of raw materials, and on average is 28 - 36 hours for plum fruits (Cabrera-Bañegil et al., 2020; Prichko, 2002; Pisano et al., 2019; Ionica et al., 2013; Michalska et al., 2016). The drying process in an oven with infrared rays led to a decrease in polyphenolic substances by $10 \%$, and vitamins from $13 \%(P)$ to $29 \%(C)$ in finished candied fruits (Table 4).

The content of macroelements in candied fruits concerning the original fresh raw materials decreased by $10-13 \%$, according to the accumulation of potassium and sodium, the following varieties were distinguished: President, Stanley, and Big Stanley (Table 5). 


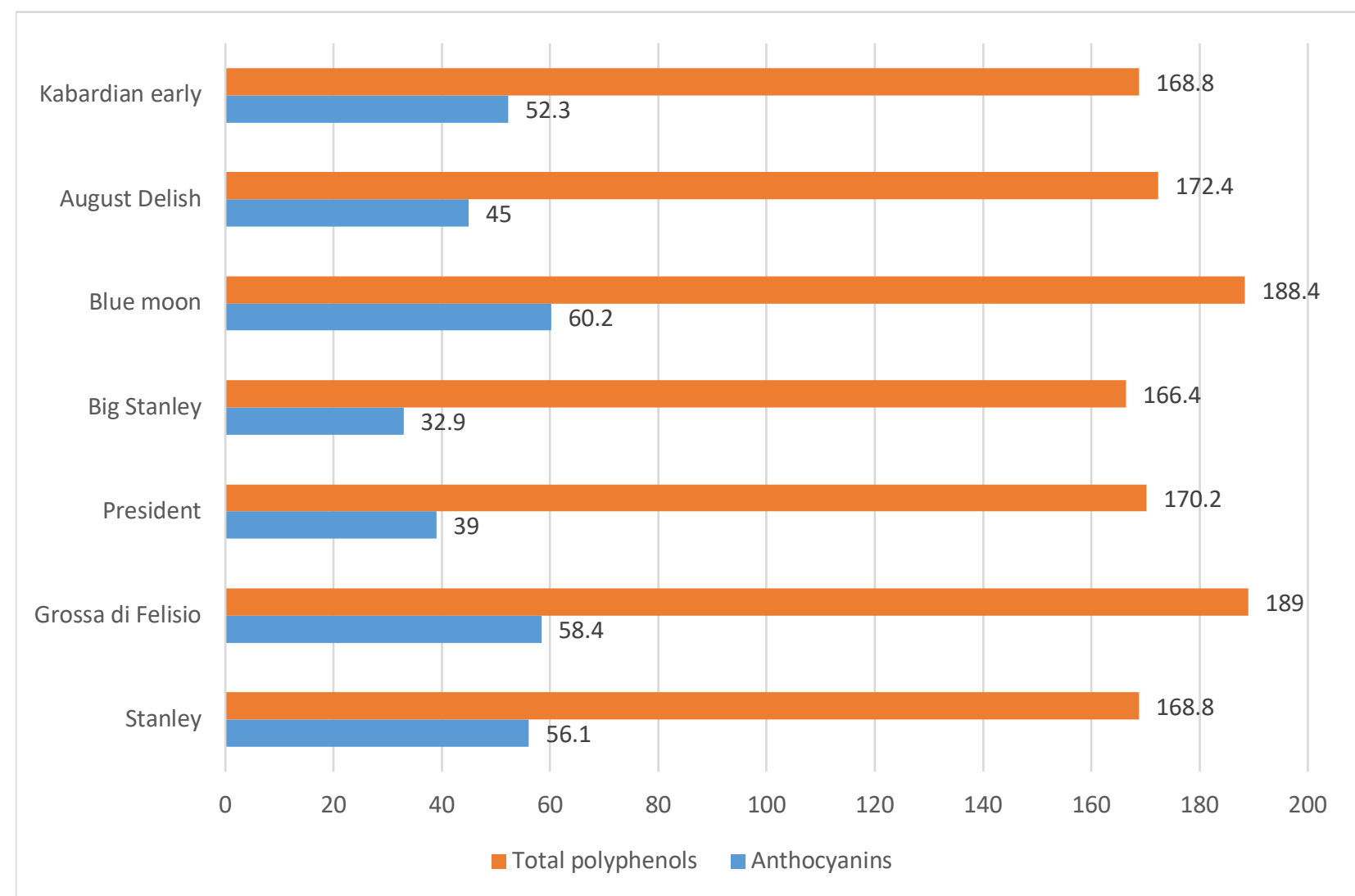

Figure 1 content of total polyphenols and anthocyanins in plum fruits depending on varietal characteristics, $\mathrm{mg} 100 \mathrm{~g}^{-1}$.

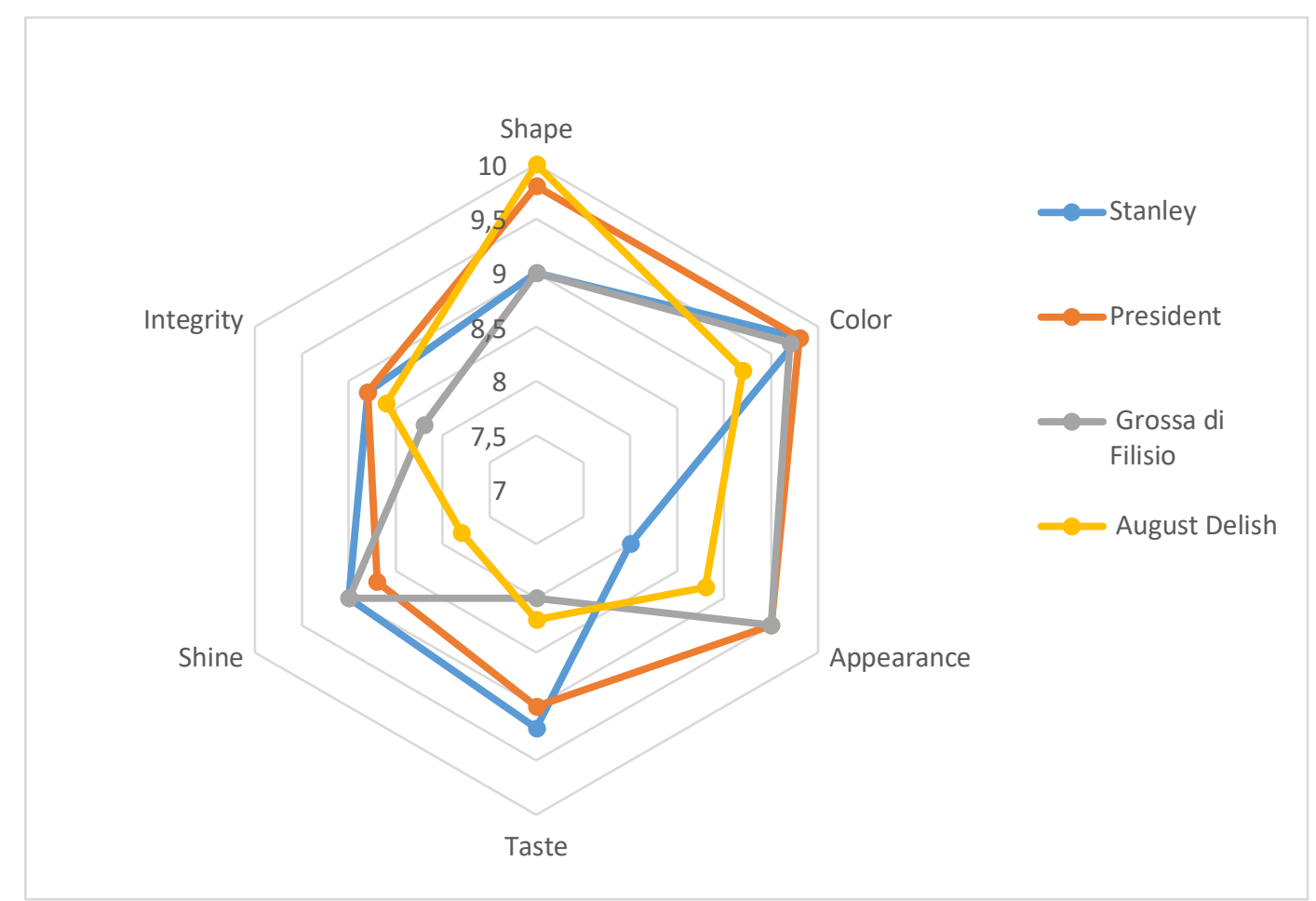

Figure 2 Organoleptic characteristics of candied fruits, taking into account varietal characteristics 

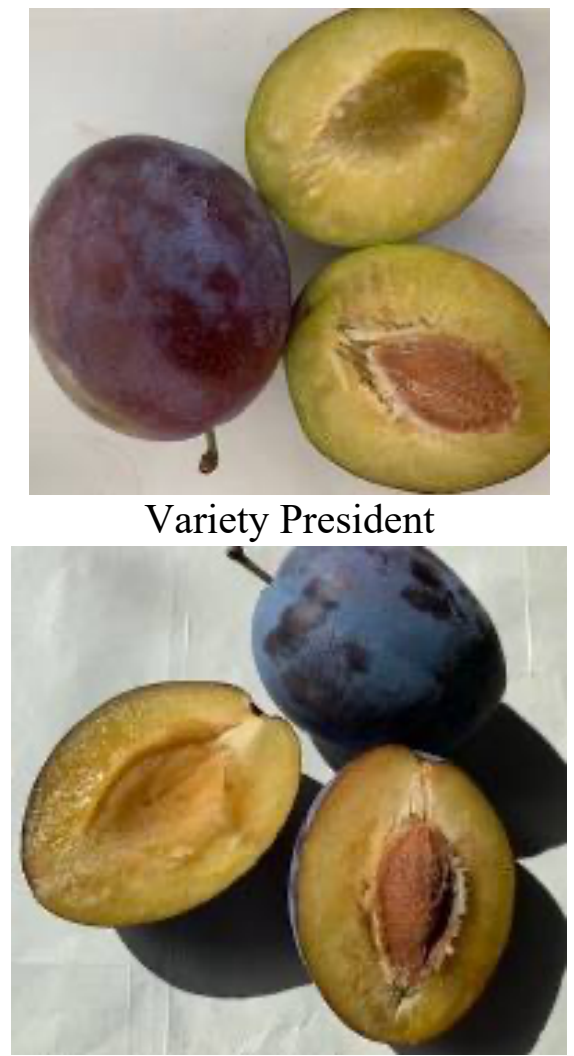

Variety Stanley

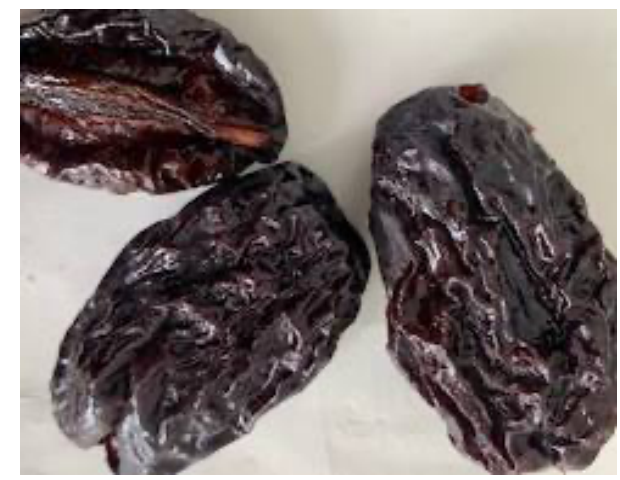

Candied fruit, variety President

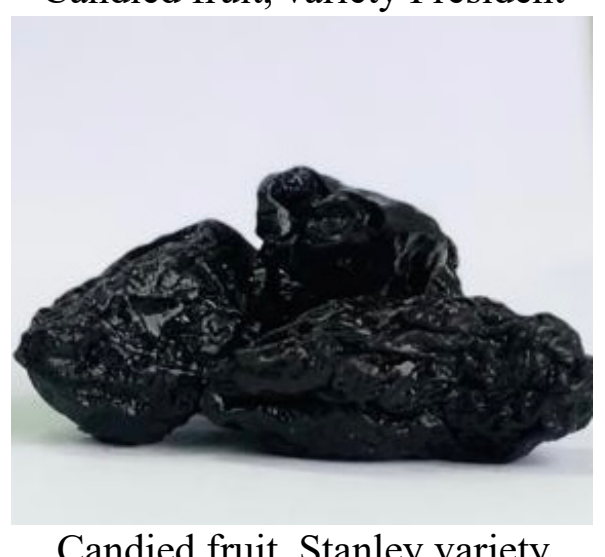

Candied fruit, Stanley variety

Figure 3 Technical indicators of the quality of candied fruits and plum fruits.

Table 1 Technical indicators of plum fruits, 2019-2020.

\begin{tabular}{|c|c|c|c|c|c|}
\hline \multirow[t]{2}{*}{ Mycotoxins } & \multicolumn{5}{|c|}{ Amet dolor sit consectetur } \\
\hline & 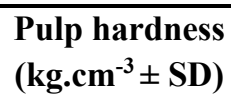 & $\begin{array}{l}\text { Weight } \\
(g \pm \text { SD) }\end{array}$ & $\begin{array}{c}\mathrm{H} \\
(\mathrm{mm} \pm \mathrm{SD})\end{array}$ & $\begin{array}{c}\mathrm{D} \\
(\mathrm{mm} \pm \mathrm{SD})\end{array}$ & $\begin{array}{c}\text { Shape index } \\
(\text { o.e } \pm \text { SD) }\end{array}$ \\
\hline $\begin{array}{c}\text { Kabardian } \\
\text { early }\end{array}$ & $3.9 \pm 0.5$ & $85.0 \pm 7.5$ & $60.4 \pm 3.5$ & $49.2 \pm 2.5$ & $1.2 \pm 0.2$ \\
\hline $\begin{array}{l}\text { August } \\
\text { Delish }\end{array}$ & $4.4 \pm 0.4$ & $140.0 \pm 5.0$ & $69.1 \pm 4.5$ & $68.2 \pm 3.5$ & $0.9 \pm 0.3$ \\
\hline Blue moon & $4.3 \pm 0.4$ & $132.0 \pm 4.5$ & $65.0 \pm 3.0$ & $64.8 \pm 2.5$ & $1.0 \pm 0.2$ \\
\hline President & $4.8 \pm 0.3$ & $122.0 \pm 8.5$ & $65.4 \pm 4.5$ & $58.8 \pm 3.0$ & $1.2 \pm 0.5$ \\
\hline $\begin{array}{c}\text { Grossa di } \\
\text { Felisio }\end{array}$ & $4.8 \pm 0.5$ & $138.0 \pm 7.5$ & $68.9 \pm 3.0$ & $66.9 \pm 2.5$ & $1.1 \pm 0.3$ \\
\hline Big Stanley & $4.4 \pm 0.5$ & $117.0 \pm 6.5$ & $70.3 \pm 2.5$ & $59.6 \pm 3.0$ & $1.3 \pm 0.2$ \\
\hline Stanley & $4.0 \pm 0.5$ & $58.0 \pm 8.5$ & $64.0 \pm 3.0$ & $44.0 \pm 3.5$ & $1.4 \pm 0.3$ \\
\hline
\end{tabular}

Table 2 Chemical composition of plum fruits, taking into account the varietal characteristics, 2019 - 2020.

\begin{tabular}{|c|c|c|c|c|c|c|}
\hline \multirow{2}{*}{ Variety } & \multirow{2}{*}{$\begin{array}{c}\text { Soluble Solids } \\
(\% \pm \text { SD })\end{array}$} & \multirow{2}{*}{$\begin{array}{l}\text { Total sugar } \\
(\% \pm \text { SD) }\end{array}$} & \multirow{2}{*}{$\begin{array}{l}\text { Acidity } \\
(\% \pm \mathrm{SD})\end{array}$} & \multirow{2}{*}{$\begin{array}{l}\text { Sugar acid } \\
\text { Index }\end{array}$} & \multicolumn{2}{|c|}{ Vitamins $\left(\mathrm{mg.100g^{-1 } \pm \mathrm { SD } )}\right.$} \\
\hline & & & & & $\mathbf{C}$ & $\mathbf{P}$ \\
\hline Kabardian early & $14.2 \pm 0.2$ & $10.4 \pm 0.1$ & $0.72 \pm 0.02$ & 14.4 & $5.0 \pm 0.5$ & $55.3 \pm 0.8$ \\
\hline August Delish & $16.6 \pm 0.3$ & $12.1 \pm 0.2$ & $1.04 \pm 0.03$ & 11.6 & $6.6 \pm 0.4$ & $51.6 \pm 0.9$ \\
\hline Blue moon & $15.4 \pm 0.3$ & $11.0 \pm 0.2$ & $1.31 \pm 0.03$ & 8.4 & $7.0 \pm 0.5$ & $39.1 \pm 0.5$ \\
\hline President & $16.2 \pm 0.1$ & $11.8 \pm 0.1$ & $0.99 \pm 0.03$ & 10.9 & $6.1 \pm 0.3$ & $53.3 \pm 0.4$ \\
\hline Grossa di Felisio & $15.8 \pm 0.2$ & $11.2 \pm 0.1$ & $1.26 \pm 0.03$ & 8.9 & $7.5 \pm 0.4$ & $70.2 \pm 0.5$ \\
\hline Big Stanley & $14.2 \pm 0.2$ & $10.4 \pm 0.2$ & $1.15 \pm 0.02$ & 9.0 & $5.7 \pm 0.3$ & $36.6 \pm 0.4$ \\
\hline Stanley & $16.2 \pm 0.2$ & $11.8 \pm 0.2$ & $0.75 \pm 0.02$ & 15.8 & $6.0 \pm 0.2$ & $72.1 \pm 0.6$ \\
\hline
\end{tabular}


Table 3 Content of macronutrients in plums, 2020.

\begin{tabular}{ccccc}
\hline Variety & \multicolumn{4}{c}{ Content $\left(\mathbf{m g . 1 0 0 g} \mathbf{1 0}^{-1}\right)$} \\
\cline { 2 - 5 } & Potassium & Sodium & Magnesium esium & Calcium \\
\hline Big Stanley & 122.4 & 29.8 & 10.5 & 13.5 \\
President & 165.0 & 23.0 & 11.1 & 17.4 \\
August Delish & 105.2 & 37.6 & 11.1 & 19.3 \\
Grossa di & 107.6 & 9.3 & 9.5 & 16.2 \\
Felisio & & & & \\
\hline
\end{tabular}

Table 4 Content of biologically active compounds in candied fruits from plum fruits.

\begin{tabular}{|c|c|c|c|c|}
\hline \multirow[b]{2}{*}{ Variety } & \multirow{2}{*}{$\begin{array}{c}\text { Total } \\
\text { polyphenols } \\
\left(\mathrm{mg.100g}^{-1}\right) \\
\end{array}$} & \multirow{2}{*}{$\begin{array}{c}\text { Anthocyanins } \\
\left(\mathbf{m g . 1 0 0 g}^{-1}\right)\end{array}$} & \multicolumn{2}{|c|}{ Vitamins (mg.100g $\left.\mathrm{g}^{-1}\right)$} \\
\hline & & & $\mathbf{C}$ & $\bar{P}$ \\
\hline August Delish & 166.4 & 39.9 & 3.8 & 42.0 \\
\hline President & 164.8 & 30.6 & 4.0 & 42.8 \\
\hline Grossa di Felisio & 185.4 & 43.7 & 5.2 & 59.6 \\
\hline Big Stanley & 152.6 & 28.8 & 4.0 & 29.8 \\
\hline Stanley & 162.8 & 40.6 & 3.8 & 60.2 \\
\hline Kabardian early & 135.4 & 18.2 & 3.2 & 42.2 \\
\hline Blue moon & 178.0 & 49.8 & 5.4 & 30.2 \\
\hline
\end{tabular}

Table 5 Content of macronutrients in candied plum fruits, 2020.

\begin{tabular}{ccccc}
\hline Variety & \multicolumn{4}{c}{ Content $\left(\mathbf{m g . 1 0 0 g} \mathbf{~}^{-\mathbf{1}}\right)$} \\
\cline { 2 - 5 } & Potassium & Sodium & Magnesium esium & Calcium \\
\hline Stanley & 118.6 & 24.7 & 9.4 & 13.1 \\
Big Stanley & 110.2 & 25.5 & 8.9 & 12.2 \\
President & 148.4 & 21.2 & 10.0 & 15.6 \\
August Delish & 96.0 & 33.8 & 10.2 & 17.1 \\
Grossa di & 98.4 & 8.8 & 9.0 & 14.8 \\
Felisio & & & & \\
\hline
\end{tabular}

Table 6 Chemical indicators of the quality of candied fruits from plum fruits.

\begin{tabular}{|c|c|c|c|c|c|c|}
\hline \multirow[b]{2}{*}{ Variety } & \multirow{2}{*}{$\begin{array}{l}\text { Ash } \\
(\% \pm \text { SD })\end{array}$} & \multirow{2}{*}{$\begin{array}{l}\text { Carbohydrates } \\
(\% \pm \text { SD) }\end{array}$} & \multirow[t]{2}{*}{ Protein $(\% \pm$ SD) } & \multicolumn{2}{|c|}{ Vitamins (mg.100g $\left.\mathrm{g}^{-1}\right)$} & \multirow{2}{*}{$\begin{array}{l}\text { Energy } \\
\text { Value } \\
\text { (kcal) } \\
\end{array}$} \\
\hline & & & & $\mathrm{C}$ & $\mathrm{P}$ & \\
\hline President & 0.8 & 45.0 & 0.5 & 4.0 & 42.8 & 147.0 \\
\hline Stanley & 0.7 & 42.0 & 0.4 & 3.8 & 60.2 & 125.0 \\
\hline
\end{tabular}

When processing experimental data for a significance level of $p=0.05$, the following statistical criteria were used: Cochran's criterion - to assess the homogenity of the variance; Student's test - to assess the significance of the calculated coefficients; Fisher's criterion - to assess the adequacy of the obtained regression equations (Moscattello et al., 2019; Michalska et al., 2016; Xiang et al., 2020).

To assess the quality of plum fruits and to highlight the best ones in terms of a set of signs, a regression, correlation analysis of technical, biochemical indicators was carried out (Reichel et al., 2017; Prichko, Machneva and Droficheva 2020). A model of the relationship between the quality of fruits ( $Y$-sensory assessment) and complex chemical indicators has been obtained. The regression equation for plum varieties looks like this at $(R=0.914)$ :
$Y=8.2-0.3 X_{1}-0.004 X_{2}+0.11 X_{3}-0.16 X_{4}+0.66 X_{5}+0.7 X_{6}$ $+0.001 X_{7}-0.0002 X_{8}$;

Where:

$-\mathrm{X}_{1}$ - is the shape index; $\mathrm{X}_{2}-$ average weight, $\mathrm{X}_{3}-$ dry matter; $\mathrm{X}_{4}-$ acidity, $\mathrm{X}_{5}-$ sugar; $\mathrm{X}_{6}-$ vitamin $C, \mathrm{X}_{7}-$ vitamin $P, \mathrm{X}_{8}-$ anthocyanins.

Good agreement between the experimental and calculated data indicates the adequacy of the found regression equations.

Organoleptic evaluation of candied plum fruits of the variety: Stanley, President, Grossa di Felisio, August Delish was carried out (Figure 2). 
The candied fruits of the plum variety Grossa di Felisio were distinguished by their pronounced sour tastes, due to the high acidity of fresh fruits.

Based on the organoleptic assessment carried out, it can be concluded that there is a prospect of using such varieties as Stanley and President for the production of candied fruits, which have a pleasant taste and appearance, with a high tasting score -4.9 points. The technical characteristics of the quality of plum and candied fruits of the following varieties have been established: President and Stanley (Figure 3).

Taking into account the peculiarities of the chemical composition of candied fruits from the fruits of plum varieties: Stanley and the President, a comparative mathematical calculation of the energy value of the finished product was made (Table 6).

The varieties that carry high valuable technical and biochemical characteristics have been identified. According to the content of biologically active substances of the 7 studied varieties, the following are distinguished: Grossa di Felisio, Blue moon, Stanley. The most valuable varieties for processing in terms of accumulation of total polyphenols, anthocyanins, vitamin C, P are Grossa di Felisio and Blue moon. According to the content of minerals (potassium, sodium, calcium), capable of maintaining the structure of fruit tissue during processing, the President variety stands out. Theoretically and experimentally confirmed the possibility of forming the quality of candied fruit based on the complex influence of the factors of the technological process, taking into account their variation within the specified limits and characteristics of varieties. According to the technical indicators that appear during processing, the fruits of the plum variety proved to be unsuitable for the production of candied fruits: variety Blue moon after the first filling with syrup, the structure of the fruit tissue changed and the finished candied fruits did not look attractive to the consumer.

According to the results of the organoleptic evaluation, candied fruits from plum fruits of the Grossa di Felisio variety were distinguished by pronounced sour tastes, due to the high acidity of fresh fruits, for the production of which it was recommended to increase the sugar consumption rate. Candied fruits from plum fruits of the August Delish variety had a pale, slightly colored appearance with a slightly harmonious taste.

\section{CONCLUSION}

Based on the studies carried out, experimental data were obtained on the influence of the varietal characteristics of plum fruits on the technological indicators of the quality of candied fruits and the yield of the finished product was determined. The results of experimental biochemical and technological analyzes of fruits at individual technological stages of production made it possible to judge the influence of varietal characteristics on the quality indicators of the finished product. For the industrial production of candied fruits, plum varieties with high biochemical and technical indicators are recommended: Stanley, Big Stanley, President, Kabardinskaya early, Grossa di Felisio.

\section{REFERENCES}

Sheikh, M. A., Saini, C. S., Sharma, H. K. 2021. Computation of design-related engineering properties and fracture resistance of plum (Prunus domestica) kernels to compressive loading. Journal of Agriculture and Food $\begin{array}{lllll}\text { Research, } & \text { vol. } & 3, & 11 & \text { p. }\end{array}$ https://doi.org/10.1016/j.jafr.2021.100101

Alekseeva, N. V., Raikhel, N. Z., Mamaeva, L. A., Khamitova, B. M., Tukhvatullin, R. Z. 2018. Technology of production of candied fruits from large-fruited red-violet cherry plums of southern Kazakhstan. Eurasian Union of Scientists (ESU), vol. 6, no. 51, p. 28-32.

Amin, R. M., Andrade, N. S., Neuman, B. J., Curr, R. 2019. Musculoskelet Med. Food Data Central, p. 25-33.

Cabrera-Bañegil, M., Lavado Rodas, N., Prieto Losada, M. H., Blanco-Cipollone, F., Moñino Espino, M. J., Muñoz de la Peña, A., Durán-Merás, I. 2020. Evolution of polyphenols content in plum fruits (Prunus salicina) with harvesting time by second-order excitation-emission fluorescence multivariate calibration. Microchemical Journal, vol. 158, 8 p. https://doi.org/10.1016/j.microc.2020.105299

Cerri, M., Rosati, A., Famiani, F., Reale, L. 2019. Fruit size in different plum species (genus Prunus L.) is determined by post-bloom developmental processes and not by ovary characteristics at anthesis. Scientia Horticulturae, vol. 255, p. 1-7. https://doi.org/10.1016/j.scienta.2019.04.064

Kim, D. O., Jeong, S. W., Lee, C. Y. 2003. Antioxidant capacity of phenolic phytochemicals from various cultivars of plums. Food Chemistry, vol. 81, no. 3, p. 321-326. https://doi.org/10.1016/S0308-8146(02)00423-5

Deiana, M., Montoro, P., Jerković, I., Atzeri, A., Marijanović, Z., Serreli, G., Piacente, S., Tuberoso, C. I. G. 2019. First characterization of Pompia intrea candied fruit: The headspace chemical profile, polar extract composition and its biological activities. Food Research International, vol. 120, p. 620-630. https://doi.org/10.1016/j.foodres.2018.11.016

Demidov, S. F., Popov, S. V., Savelyev, V. A. 2015. A new word in science: development prospects, vol. 4, no. 6, p. 92-93.

Doroshenko, T. N., Ryazanova, L. G., Maksimtsov, D. V. 2015. Role of boron in optimization plum on the South of Russia. Fruit and berry growing in Russia, vol. 42, p. 272-276.

Eremin, G. V., Provorchenko, A. V., Gavrish, V. F., Podorozhnyi, V. N., Eremin, V. G. 2000. Stone fruit crops. Cultivation on clonal rootstocks and own roots. Rostov-on Don, Russia : Feniks, 256 p. ISBN 5-222-00537-2.

Eremin, G. V., Zaremuk, R. S., Alehina, E. M., Kritskii, E. I. 2009. Atlas of the best varieties of fruit and berry crops of the Krasnodar Territory, Stone cultures. Krasnodar, Russia : GNU SKZNIISIV of the Russian Agricultural Academy, $134 \mathrm{p}$.

González, M., Salazar, E., Cabrera, S., Olea, P., Carrasco, B. 2016. Analysis of anthocyanin biosynthesis genes expression profiles in contrasting cultivars of Japanese plum (Prunus salicina L.) during fruit development. Gene Expression Patterns, vol. 21, no. 1, p. 54-62. https://doi.org/10.1016/j.gep.2016.06.005

González-Cebrino, F., Durán, R., Delgado-Adámez, J., Contador, R., Ramírez, R. 2013. Changes after high-pressure processing on physicochemical parameters, bioactive compounds, and polyphenol oxidase activity of red flesh and peel plum purée. Innovative Food Science \& Emerging Technologies, vol. $20, \quad$ p. 34-41. https://doi.org/10.1016/j.ifset.2013.07.008

Gościnna, K., Pobereżny, J., Wszelaczyńska, E., Szulc, W., Rutkowska, B. 2021. Effects of drying and extraction methods on bioactive properties of plums. Food Control, vol. 122, 11 p. https://doi.org/10.1016/j.foodcont.2020.107771 
GOST ISO standart 2173. 2014 Interstate standard. Products of processing fruits and vegetables. Refractometric method for the determination of soluble solids, $7 \mathrm{p}$.

GOST standart 24556. 2014. Products of fruits and vegetables processing. Methods for determination of vitamin C. 7 p.

GOST standart 25555.0. 1982. Fruit and vegetable products. Methods for determination of titratable acidity. $9 \mathrm{p}$

GOST standart 26313. 2013. Fruit and vegetable products. Acceptance rules and methods of sampling. $8 \mathrm{p}$.

GOST standart 26671. 2014. Fruit and vegetable products, canned meat, and meat-vegetable products. Preparation of test samples for laboratory analyzes. $4 \mathrm{p}$.

GOST standart 28322. 2014. Processed fruits, vegetables and mushrooms. Terms and definitions. $11 \mathrm{p}$.

GOST standart 31745. 2012. Food products. Determining the content of polycyclic aromatic hydrocarbons by means of highly effective liquid chromatography. $10 \mathrm{p}$.

GOST standart 32709. 2014. Juice products. Methods for the determination of anthocyanins. $20 \mathrm{p}$.

GOST standart 8756.13. 1987. Fruit and vegetable products. Methods for determination of sugars. $11 \mathrm{p}$.

Igwe, E. O., Charlton K. E. 2016. A Systematic Review on the Health Effects of Plums (Prunus domestica and Prunus salicina). Phytotherapy Research, vol. 30, no. 5, p. 701-731. https://doi.org/10.1002/ptr.5581

Ionica, M. E., Nour, V., Trandafir, I. Cosmulescu, S., Botu, M. 2013. Physical and chemical properties of some European Plum cultivars (Prunus domestica L.). Notulae Botanicae Horti Agrobotanici Cluj Napoca, vol. 41, no. 2, p. 499-503. https://doi.org/10.15835/nbha4129354

Kaufmane, E., Scrivele, M., Rubauskis, E., Ikase, L. 2007. The yield and fruit quality of two plum cultivars on different rootstocks. Sodininkystè ir Daržininkystè, vol. 26, no. 3, p. 1015 . Available

at: https://www.cabdirect.org/cabdirect/abstract/20073291763

Li, L., Yu, Y., Xu, Y., Wu, J., Yu, Y., Peng, J., An, K., Zou, B., Yang, W. 2021. Effect of ultrasound-assisted osmotic dehydration pretreatment on the drying characteristics and quality properties of Sanhua plum (Prunus salicina L.). LWT, vol. 138, 7 p. https://doi.org/10.1016/j.lwt.2020.110653

Qin, L., Wang, H., Zhang, W., Pan, M., Xie, H., Guo, X. 2020. Effects of different drying methods on phenolic substances and antioxidant activities of seedless raisins. $L W T$, vol. 131, 8 p. https://doi.org/10.1016/j.lwt.2020.109807

Makarova, N. V., Eremeeva, N. B. 2015. Antioxidant Activity of Plum Extracts. In Modern food technologies. $2^{\text {nd }}$ edition, International Scientific and Practical Conference, p. 97-99.

Meretukova, F. N. 2012. ТЕХНОЛОГИЧЕСКАЯ ОЦЕНКА СЛИВЫ РУССКОЙ ДЛЯ ПРОМЫШЛЕННОЙ ПЕРЕРАБОТКИ (Technological evaluation of Russian plum for industrial processing). New Technologies, no. 1. p. 41-45. Available at: http://lib.mkgtu.ru/images/stories/journalnt/2012-01/008.pdf

Michalska, A., Wojdyło, A., Lech, K., Łysiak, G. P., Figiel, A. 2016. Physicochemical properties of whole fruit plum powders obtained using different drying technologies. Food $\begin{array}{lllll}\text { Chemistry, } & \text { vol. } & 207 & \text { p. } & 223-232\end{array}$ https://doi.org/10.1016/j.foodchem.2016.03.075

Milskaya, A. D. 1998. Healing foods. Food is medicine, medicine is food. 479 p. ISBN 966-03-0352-1.

Moscatello, S., Frioni, T., Blasi, F., Proietti, S., Pollini, L., Verducci, G., Rosati, A., Walker, R. P., Battistelli, A., Cossignani, L., Famiani, F. 2019. Changes in Absolute Contents of Compounds Affecting the Taste and Nutritional Properties of the Flesh of Three Plum Species Throughout
Development. Foods, vol. 8, no. 10, 18 p. https://doi.org/10.3390/foods8100486

Xiang, N., Wen, T., Yu, B., Li, G., Li, C., Li, W., Lu, W., $\mathrm{Hu}$, J. 2020. Dynamic effects of post-harvest preservation on phytochemical profiles and antioxidant activities in sweet corn kernels. International Journal of Food Science \& Technology, vol. 55, no. 9, p. 3111-3122. https://doi.org/10.1111/ijfs.14575

Islam, N., Amin, R., Shahid, M., Amin, M., Zaib, S., Iqbal, J. 2017. A multi-target therapeutic potential of Prunus domestica gum stabilized nanoparticles exhibited prospective anticancer, antibacterial, urease-inhibition, anti-inflammatory and analgesic properties. BMC Complementary and Alternative Medicine, 17 p. https://doi.org/10.1186/s12906017-1791-3

Nunes, C., Rato, A. E., Barros, A. S., Saraiva, J. A., Coimbra, M. A. 2009a. Search for suitable maturation parameters to define the harvest maturity of plums (Prunus domestica L.): A case study of candied plums. Food Chemistry, vol. 112, no. 3, p. 570-574. https://doi.org/10.1016/j.foodchem.2008.06.007

Nunes, C., Santos, C., Pinto, G., Silva, S., Lopes-da-Silva J. A., Saraiva, J. A., Coimbra, M. A. 2009b. Effects of ripening on microstructure and texture of "Ameixa d'Elvas" candied plums. Food Chemistry, vol. 115, no. 3, p. 1094-1101. https://doi.org/10.1016/j.foodchem.2008.12.089

Pisano, R., Arsiccio, A., Nakagawa, K., Barresi, A. A. 2019. Tuning, measurement and prediction of the impact of freezing on product morphology: A step toward improved design of freeze-drying cycles. Drying Technology, vol. 37, no. 5, p. 579599. https://doi.org/10.1080/07373937.2018.1528451

Popova, V., Sergeeva, N., Yaroshenko, O., Kuznetsova, A. 2020. Physiological state of plants and quality of plum fruits grafted on the rootstocks of various strength of growth depending on the plant nutrition mode. Potravinarstvo Slovak Journal of Food Sciences, vol. 14, p. 1075-1087. https://doi.org/10.5219/1469

Prichko, T. G. 2002. Biochemical and technological bases of intensification of production, storage and processing of fruits and berries. Krasnodar. $54 \mathrm{p}$.

Prichko, T. G. 2009. Regularities of the accumulation of vitamins and polyphenols in fruits and berries. Fruit growing, vol. 21 , p. $365-373$

Prichko, T. G., Droficheva, N. V. 2019. Use of fruit and berry raw materials for canned products, taking into account varietal characteristics. $24 \mathrm{p}$.

Prichko, T. G., Machneva, I. A., Droficheva, N. V. 2020. Prerequisites for the implementation of digital technologies in the production of food products based on vegetable raw materials. Fruit growing and viticulture of the South of Russia, vol. 61, no. 1, p. 122-137. https://doi.org/10.30679/2219-53352020-1-61-122-137

Methods of analysis. 2002. Products of fruits and vegetables. IPK Publishing house of standards, $200 \mathrm{p}$.

Reichel, N. S., Alexeyeva, N. V., Jaishibekov, G. S., Kaipova, J. N. 2017. СПОСОБЫ ПРОИЗВОДСТВА ЦУКАТОВ (Ways to produce candied fruit). International Journal of Applied and Fundamental Research, vol. 2, p. 168171. (In Russian) Available at: https://appliedresearch.ru/ru/article/view?id=11238

Richmond, R., Bowyer, M., Vuong, Q. 2019. Australian native fruits: Potential uses as functional food ingredients. Journal of Functional Foods, vol. 62, 16 p. https://doi.org/10.1016/j.jff.2019.103547

Sommano, S., Caffin, N., McDonald, J., Cocksedge, R. 2013. The impact of thermal processing on bioactive compounds in Australian native food products (bush tomato and Kakadu 
plum). Food Research International, vol. 50, no. 2, p. 557-561. https://doi.org/10.1016/j.foodres.2011.03.008

Sullivan, V. K., Na, M., Proctor, D. N., Kris-Etherton, P. M., Petersen, K. S. 2020. Consuption of Dried Fruits is Associated with Greater Intakes and Better Diet Quality in US Adults: A Cross-Sectional Analysis of the National Health and Nutrition Examinatoin Survey. Journal of the Academy of Nutrition and Dietetics, vol. 121, no. 7, p. 1258-1272. https://doi.org/10.1016/j.jand.2020.08.085

Svanes, E, Johnsen, F. M. 2019. Environmental life cycle assessment of production, processing, distribution and consumption of apples, sweet cherries and plums from conventional agriculture in Norway. Journal of Cleaner Production, vol. 238, p. 15 p. https://doi.org/10.1016/j.jclepro.2019.117773

Turaeva, N. I. 2017. Medicinal properties of plums. Biology and integrative medicine, no. 1. Available at: https://cyberleninka.ru/article/n/lechebnye-svoystvaslivy/viewer

Vigorov, L. I. 1972. Method of determination of R-active agents. Proceedings of the III workshop on BAS. Sverdlovsk, $362 \mathrm{p}$.

Yakuba, Y. F., Kuznetsova, A. P., Lozhnikova, M. S. 2011. The use of capillary electrophoresis and extraction in the microwave field for the analysis of plant raw materials. Separation and concentration in analytical chemistry and radiochemistry: Proceedings of the III All-Russian. symposium, $153 \mathrm{p}$.
Funds:

This research received no external funding.

\section{Conflict of Interest:}

The authors declare no conflict of interest.

\section{Ethical Statement:}

This article does not contain any studies that would require an ethical statement.

\section{Contact Address:}

*Tatiana Prichko, Dr. Agric. Sci., Federal State Budget Scientific Institution "North Caucasian Federal Scientific Center of Horticulture, Viticulture, Wine-making", 40th anniversary of Victory Street, 39, Krasnodar, Russia, 350901, Tel.: +79184488975,

E-mail: Prichko@yandex.ru

ORCID: https://orcid.org/0000-0001-5153-8482

Natalya Droficheva, Cand. Teh. Sci., Federal State Budget Scientific Institution "North Caucasian Federal Scientific Center of Horticulture, Viticulture, Wine-making", 40th anniversary of Victory Street, 39, Krasnodar, Russia, 350901, Tel.: +79618554464,

E-mail: Droficheva.nata@icloud.com

ORCID: https://orcid.org/0000-0003-1552-159X

Corresponding author: * 